\title{
Market development and investment potential in the Odessa region
}

\begin{abstract}
This articles explores the situation of the city and oblast of Odessa, a part of Ukraine on the Black Sea coast, from the perspective of its relative attractiveness to foreign investors, with a focus particularly on Germany, the largest foreign investor in Ukraine. Ukraine has come some way since independence but obstacles do remain to its further development, including a need to find the right balance of independence and partnership with other states in the region and, indeed, with the EU, with several of whose member states it shares borders. The oblast has a number of natural advantages stemming from its location, in particular in transport and tourism, but the article focuses critically on the range of resources that the area has which make up the building blocks of economic activity. Production and output in a number of key industries and markets are also examined, as are the opportunities and risks to foreign investors of investing in Ukraine and the relative attractiveness of investing in Odessa. The article concludes with a SWOT analysis of Odessa.
\end{abstract}

Keywords: Ukraine, CIS, foreign direct investment, natural resources, foreign trade, development activity, investment climate, opportunities and risks, EU accession, SWOT analysis

An autonomous state situated between the European Union and the Commonwealth of Independent States (CIS), Ukraine has undergone rapid political and economic development since its political independence in 1991. By itself, the outstanding geographical position between the economic powers of the EU and Russia is a special attraction to companies. However, the fundamental requirements for market economic development - mineral resources and qualified and low-priced human resources - appear also to be given.

This development, however, is not taking place without obstacles and conflicts. Ukraine's population is still strongly divided along political lines, as one could observe on the basis of the last parliamentary elections. One example is the current argument with Russia on the issue of gas provision, embossed as it is with the making of threatening gestures. At first sight, one can see that Ukraine still has to find the right balance between independence and partnership as regards other Eurasian states.

Those who seek to gain ground in this country should be aware of these peculiarities in order to be able to manage the risks which are also present. However, one should be encouraged by the plenty of successful examples of, for instance, German companies which have already established themselves in Ukraine: statistical data show that German direct investment amounted to $\$ 5678 \mathrm{~m}$ between 1 January and 1 July 2007, i.e. $23.5 \%$ of all foreign direct investment. 
Odessa itself, due to its immediate position on the Black Sea, has a unique position in the sectors of transport and tourism. Hence, it makes an important contribution to Ukraine's infrastructure.

\section{Economic conditions in the Odessa region}

The region's position in a national comparative perspective

A national comparative perspective allows the rating and analysing of the regions of Ukraine. With dynamic and investment ratings, the economic performances of single regions can be measured while industrial activity analysis gives insight to the production levels in each single Ukrainian region.

Investment and dynamic ratings of the regions

Using these regional ratings, the economic performance of Ukraine's regions can be measured. The two different ratings allow us to analyse trends in the changes in the most important economic indexes throughout a given period of time, as well as to identify the current level of development.

The findings here are made up of two ratings: the investment rating and the dynamic rating. The investment rating assesses the region's position according to structural characteristics such as economic development, infrastructure, financial sector, human capital, company structure and local administration. The dynamic rating says much about the region's economic potential using thirteen different indicators, including industrial production, the rate of unemployment, wage development, exports and commercial turnover.

Table 1 - Regional ratings for $\mathbf{2 0 0 5}^{1}$

\begin{tabular}{|l|c|c|}
\hline & Investment rating & Dynamic rating \\
\hline City of Kiev & 1 & 3 \\
\hline Charkiv & 2 & 13 \\
\hline Dnipropetrovsk & 3 & 14 \\
\hline Odessa & 4 & 20 \\
\hline Donetsk & 5 & 10 \\
\hline Zaporischja & 6 & 9 \\
\hline Lviv & 7 & 23 \\
\hline Poltava & 8 & 4 \\
\hline Kiev region & 9 & 16 \\
\hline Autonomous Republic of Crimea & 10 & \\
\hline
\end{tabular}

1 Institute for Reforms, Ukraine. Ratings for 2006 and 2007 are not yet available. 


\begin{tabular}{|l|c|c|}
\hline & Investment rating & Dynamic rating \\
\hline Zakarpatta & 11 & 2 \\
\hline Tscherkassy & 12 & 7 \\
\hline Mykolaiv & 13 & 22 \\
\hline Tscherniwzi & 14 & 24 \\
\hline Vinnitsya & 15 & 6 \\
\hline Rivne & 16 & 18 \\
\hline Volyn & 17 & 11 \\
\hline Khmelnytskyj & 18 & 1 \\
\hline Kirovohrad & 19 & 21 \\
\hline Chernihiv & 20 & 8 \\
\hline Ivano-Frankivsk & 21 & 5 \\
\hline Luhansk & 22 & 17 \\
\hline Ternopil & 23 & 26 \\
\hline Sumy & 24 & 12 \\
\hline Cherson & 25 & 19 \\
\hline Zhytomyr & 26 & \\
\hline
\end{tabular}

The Odessa region takes fourth place in the investment rating after Kiev, Charkiv and Dnipropetrovsk. In contrast, in the dynamic rating the region only reached twentieth place. Given its high potential, the Odessa region has, however, both good and promising prospects.

\section{Industrial activity analysis}

Production volume grew by $11 \%$ across the entire Ukraine in the period from January to October 2007 compared to the period from January to October 2006. The Odessa region lies in tenth position, with a growth rate of $13.6 \%$. Ranked in the top positions of the regions regarding production are Volyn (40\%), Tscherkassy (26.8\%), Tscherniwzi $(22.5 \%)$, Zakarpattja (21.1\%) and, in fifth position, Zaporischja (19\%). 
Table 2 - Percentage growth rate of the volume of industrial production (decline shown by minus sign) ${ }^{2}$

\begin{tabular}{|c|c|c|c|c|}
\hline & $\begin{array}{l}\text { October } \\
2007 \text { on } \\
\text { Septem- } \\
\text { ber } 2007\end{array}$ & $\begin{array}{c}\text { October } \\
2007 \text { on } \\
\text { October } \\
2006\end{array}$ & Ranking & $\begin{array}{c}\text { January- } \\
\text { October } \\
2007 \text { on } \\
\text { January- } \\
\text { October } \\
2006\end{array}$ \\
\hline Ukraine & 10.2 & 13.7 & 14 & 11 \\
\hline Autonomous Republic of Crimea & 6.1 & 14.6 & 12 & 11.6 \\
\hline \multicolumn{5}{|l|}{ Regions: } \\
\hline City of Kiev & 1.2 & 18.5 & 19 & 8.9 \\
\hline Charkiv & 10.5 & 12 & 16 & 9.3 \\
\hline Dnipropetrovsk & 5.5 & 5.7 & 24 & 6.7 \\
\hline Odessa & 13.8 & 22.1 & 10 & 13.6 \\
\hline Donetsk & 5.5 & 8.8 & 17 & 9.2 \\
\hline Zaporischja & 11.9 & 23.5 & 5 & 19 \\
\hline Lviv & 6.3 & 11.3 & 12 & 11.6 \\
\hline Poltava & 1.4 & -5.3 & 18 & 9 \\
\hline Kiev region & 14.5 & 6.8 & 15 & 9.4 \\
\hline Zakarpattja & 11.1 & 19.5 & 4 & 21.1 \\
\hline Tscherkassy & 17.7 & 27.6 & 2 & 26.8 \\
\hline Mykolaiv & 9.6 & 5.7 & 22 & 8.5 \\
\hline Tscherniwzi & 8.5 & 27.6 & 3 & 22.5 \\
\hline Ivano-Frankivsk & 20.5 & 26.6 & 26 & -1 \\
\hline Luhansk & 11.8 & 61.4 & 9 & 14.6 \\
\hline Ternopil & 88 & 5.9 & 6 & 17.4 \\
\hline Sumy & 10.5 & 12.1 & 23 & 7.4 \\
\hline Cherson & 21.5 & 3.5 & 21 & 8.6 \\
\hline Zhytomyr & 16.4 & 5 & 14 & 10.1 \\
\hline City of Sevastopol & -1.2 & 5 & 13 & 10.3 \\
\hline Volyn & 27.1 & 67.1 & 1 & 40 \\
\hline
\end{tabular}

2 Ukrainian Committee for Statistics. 


\begin{tabular}{|l|c|c|c|c|}
\hline & $\begin{array}{c}\text { October } \\
\mathbf{2 0 0 7} \text { on } \\
\text { Septem- } \\
\text { ber 2007 }\end{array}$ & $\begin{array}{c}\text { October } \\
\mathbf{2 0 0 7} \text { on } \\
\text { October } \\
\mathbf{2 0 0 6}\end{array}$ & Ranking & $\begin{array}{c}\text { January- } \\
\text { October } \\
\text { 2007 on } \\
\text { January- } \\
\text { October } \\
\mathbf{2 0 0 6}\end{array}$ \\
\hline Vinnitsya & 36 & -0.7 & 20 & 8.7 \\
\hline Kirovohrad & 32.3 & 1.2 & 11 & 12.6 \\
\hline Rivne & 19.6 & 10.2 & 8 & 15 \\
\hline Khmelnytskyi & 18.2 & 10.9 & 7 & 16.2 \\
\hline Chernihiv & 12.1 & 10.7 & 25 & 6.6 \\
\hline
\end{tabular}

Across the entire Ukraine, $58.1 \%$ of firms show a growth of production while in $33.6 \%$ production declined. Just over $8 \%$ of firms ran without production.

\section{Table 3 - Company ratings regarding production volume ${ }^{3}$}

\begin{tabular}{|l|c|c|c|}
\hline & $\begin{array}{c}\text { Growth of } \\
\text { industrial } \\
\text { volume of } \\
\text { production }\end{array}$ & $\begin{array}{c}\text { Decline of } \\
\text { industrial } \\
\text { volume of } \\
\text { production }\end{array}$ & $\begin{array}{c}\text { Firms without } \\
\text { production in } \\
\text { October 2007 }\end{array}$ \\
\hline Ukraine & 58.1 & 33.6 & 8.3 \\
\hline Autonomous Republic of Crimea & 45.6 & 43.5 & 10.9 \\
\hline Regions: & & & 57.8 \\
\hline City of Kiev & 58.3 & 35.8 & 5.9 \\
\hline Charkiv & 57.5 & 29.0 & 13.5 \\
\hline Dnipropetrovsk & 50.5 & 42.3 & 7.2 \\
\hline Odessa & 62.0 & 34.2 & 3.8 \\
\hline Donetsk & 57.6 & 38.7 & 3.7 \\
\hline Zaporischja & 62.2 & 32.5 & 5.3 \\
\hline Lviv & 60.9 & 32.9 & 6.2 \\
\hline Poltava & 61.3 & 30.0 & 8.7 \\
\hline Kiev region & 59.6 & 31.8 & 8.6 \\
\hline Zakarpattja & 58.3 & 33.8 & 7.9 \\
\hline Tscherkassy & 49.6 & 40.1 & 10.3 \\
\hline Mykolaiv & & & \\
\hline
\end{tabular}

3 Ukrainian Committee for Statistics. 


\begin{tabular}{|l|c|c|c|}
\hline & $\begin{array}{c}\text { Growth of } \\
\text { industrial } \\
\text { volume of } \\
\text { production }\end{array}$ & $\begin{array}{c}\text { Decline of } \\
\text { industrial } \\
\text { volume of } \\
\text { production }\end{array}$ & $\begin{array}{c}\text { Firms without } \\
\text { production in } \\
\text { October 2007 }\end{array}$ \\
\hline Tscherniwzi & 55.9 & 32.8 & 11.3 \\
\hline Ivano-Frankivsk & 61.1 & 31.8 & 7.1 \\
\hline Luhansk & 60.1 & 32.6 & 7.3 \\
\hline Ternopil & 59.2 & 29.6 & 11.2 \\
\hline Sumy & 55.3 & 36.3 & 8.4 \\
\hline Cherson & 56.1 & 32.1 & 11.8 \\
\hline Zhytomyr & 59.4 & 32.0 & 8.6 \\
\hline City of Sevastopol & 50.6 & 39.5 & 9.9 \\
\hline Volyn & 55.7 & 35.8 & 8.5 \\
\hline Vinnitsya & 58.0 & 27.6 & 14.4 \\
\hline Kirivohrad & 57.1 & 28.7 & 14.2 \\
\hline Rivne & 56.2 & 32.1 & 11.7 \\
\hline Khmelnytskyi & 58.4 & 31.8 & 9.8 \\
\hline Chernihiv & 62.2 & 27.7 & 10.1 \\
\hline
\end{tabular}

Firms in the Odessa region show a similar picture. Here, $50.5 \%$ have raised their production volume. The results depend, of course, on regional and seasonal factors.

Hence, the macroeconomic development of Ukraine may be assessed positively. Foreign investments reflect these results.

\section{Focus analysis}

The following focus analysis describes the most important parts of economic activity in the Odessa region.

\section{Raw materials}

Mineral resources in this area are limited. Above all, there are raw materials for the construction sector (sand, limestone, loam, granite) and occurrences of subterranean mineral water. On the territory of the Odessa area, there are minor deposits of brown and black coal, natural gas and mineral oil which may be explored. There are also ore and gold deposits, but those are not exploited because they are not yet well explored geologically. Hence, the region's resources form an important raw material foundation for the development of metallurgy, chemicals and the building materials and stoneware industries. 


\section{Human resources}

The Odessa region is characterised by a large variety of settled nationalities: more than one hundred nationalities live in the Odessa administrative district. The population is distinguished by being comparatively highly trained, but there is a bottleneck concerning workers who have many years of experience. This can lead to difficulties in handling modern technology or in understanding the market economy. Such staff also have only limited experience with complex procedures and much personal initiative is required because most of the personnel is still used to orienting themselves around tightly-formulated instructions.

The unemployment rate in Ukraine is officially $3.5 \%$. The percentage of citizens in the labour force amounts to $57.3 \%$ of the total population. The labour force is divided between different industries as in Figure 1.

With a little less than $10 \%$ of the workforce, the transport sector plays a key role in the labour market. However, the Odessa region is also distinguished by its important scientific-technical potential. Not only is it the centre of training for Ukrainian specialists, but it is also the centre of research and development.

Gross wages in Ukraine are among the lowest in Europe. Everywhere, the country lacks trained skilled workers and managers with experience of a market economy. Recruitment is considered difficult and time consuming. Currently, wages in Ukraine are at the following levels: for unskilled labour, $€ 100$; for a skilled worker, $€ 150$ $€ 200$; for an employee in sales, $€ 400-€ 600$; and for a manager with responsibility, $€ 500-€ 1500$.

\section{Figure 1 - Division of the labour force by industry}

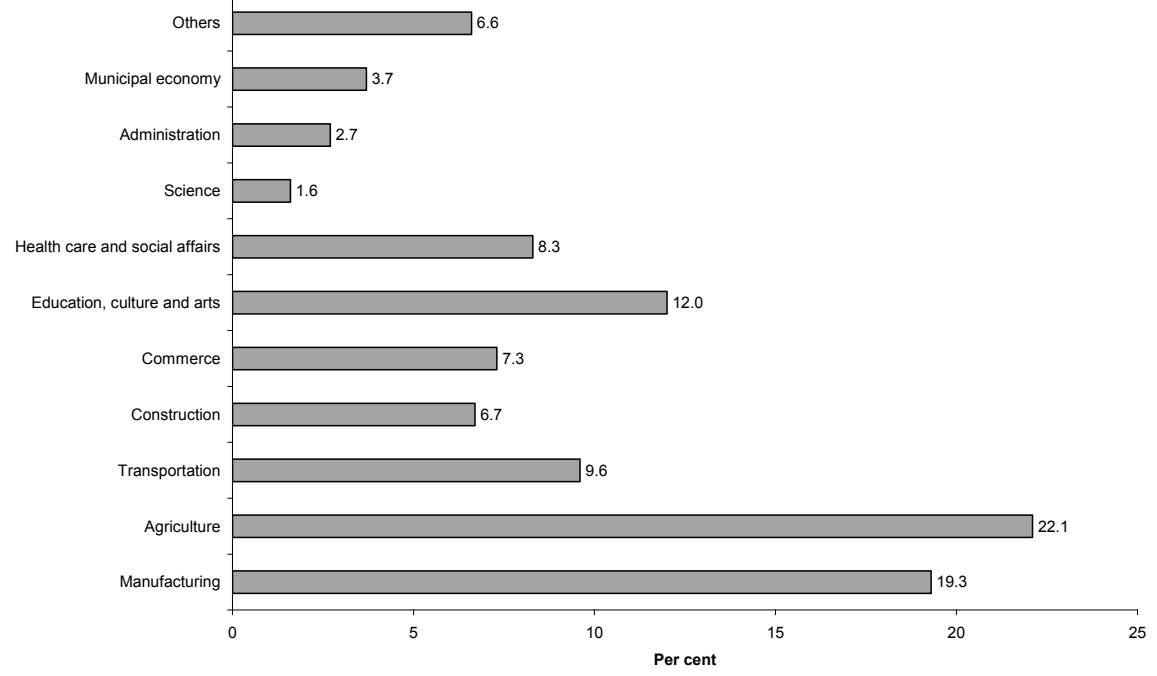


Figure 2 - Assessment of characteristics of Ukrainian personnel (1= excellent; 5 = unsatisfactory)



Generally, it is no great problem to find well-trained personnel where needed, particularly in large cities. However, especially the beginning of a start-up enterprise should not be carried out without a foreign managing director: the introduction of corporate culture and quality standards, and the control of business processes, are handled more easily and faster this way. It is important to note in this context that all foreign employees in Ukraine need a labour permit, including foreign managing directors. An application for a labour permit can first be made after the foundation of branch; in the meantime, the company may not dispose of an authorised management team but a solution can be found for example by appointing an interim manager from Ukraine.

Odessa is an important centre of research and development in Ukraine. The largest educational institutions are the National Metschnikov University, the National Technical University, the National Marine University and the Odessa State A. V. Nezhdanova Music Academy. On 1 January 2007, 54 universities existed in the area of Odessa. The universities' scientific and teaching staff number more than 9000 people, among them $770 \mathrm{PhDs}(8.4 \%), 807$ professors $(8.8 \%), 3975$ candidates $(43.3 \%)$ and 3075 lecturers $(33.5 \%)$. In the area of Odessa, many institutions are involved in research and development: 19 universities; the Scientific Centre South of the National Academy of Science of Ukraine; and the Ministry of Education, with five branches. Moreover, there are 27 research institutes, eleven development and project institutions and nine branches of the resort academies. 


\section{Infrastructure}

The infrastructure of the Odessa region compares well with the entire Ukraine. Hence, its structure will be illustrated here within the national context.

\section{Railway}

$20 \%$ of Ukraine's transportation of goods is accounted for by the Odessa railway company. Hence, it is an important part of Ukraine's transportation flow and spans six areas: Odessa, Nikolaev, Cherson, Kirovohrad, Vinnitsya and Tscherkassy. Its length amounts to $4200 \mathrm{~km}$. The biggest railway stations are to be found in Odessa, Reni, Nikolaev, Ilyichevsk and Cherson.

The itineraries of international transport routes cross the region: Helsinki-KievOdessa-Alexandropouli; and Europe-Caucasus-Asia. Thus, foreign trade transport connections with more than seventy countries are assured.

The Odessa railway is used to most railway capacity being directed to the seaports: from Vinnitsya and Tscherkassy to Odessa and Ilyichevsk; and from Znamenka, Dnipropetrovsk and Donetsk both to Nikolaev as well as to Cherson. Among the goods mostly transported in the direction of Odessa, Ilyichevsk and Yuzhny are petroleum products, black coal, ferrous metals and mineral construction materials. A part thereof is converted and used in Odessa, which is the biggest industrial centre in the Ukrainian Black Sea area. The greater part, however, is transhipped and exported on the sea. In the opposite direction, from Ilychevsk and Odessa, are transported sugar, machines, metal products and tropical fruits. It has to be noted that the total amount of incoming goods is double the amount of shipped goods. To a high degree, the region is an import area regarding rail freight traffic.

In the direction of Nikolaev and Cherson, goods are transported via the seaports in the area of the River Dnepr. Black coal, petroleum products, ferrous metal, iron ore and cement comes from the Donetsk region. Petroleum products, corn and clay go in the opposite direction.

In the Odessa region, $256 \mathrm{~km}$ of the railway line have been repaired and $226.8 \mathrm{~km}$ modernised. Hence, the velocity of trains has been increased for an entire length of $433.9 \mathrm{~km}$.

\section{Road traffic}

More than 92000 lorries circulate in Ukraine's road traffic system. In 2005, transport performance on the road haulage system amounted to $8.2 \mathrm{bn} \mathrm{km}$ and $127 \mathrm{~m}$ tonnes were transported. In particular, cross-border lorry traffic has grown massively, from 207000 in 2002 to about 400000 in 2005.

Up to now, 35 government agreements on international road goods traffic have been signed. Ukraine has also signed eight international conventions, agreements and protocols in the area of goods transportation, especially in the field of international tariff conventions. The European agreements which have been conducted so as to integrate Ukraine into the European transport system assure constant growth in the international transportation of goods; for instance, the agreement on international goods transportation sets out conditions for the transport of hazardous materials and uniform labelling. 
The Ukrainian road network is based on the medieval roads of the region as well as on $20^{\text {th }}$ century development ideas. Its ray-like, or vectoral composition, complies with original traffic needs and planning. Currently, it covers $169500 \mathrm{~km}$ of public roads (5 $100 \mathrm{~km}$ in the directions of international and national transport passageways) and $150000 \mathrm{~km}$ navigated roads.

The most important traffic arteries are listed in Figure 3 below. The evident centrality of Kiev is notable: almost every traffic artery named as such by the Ministry of Transport and Communications is connected to Kiev.

\section{Figure 3 - Important traffic routes ${ }^{4}$}

\begin{tabular}{|l|}
\hline Kiev - Odessa/llyichevsk \\
\hline Kiev - Kowel - Jahodyn (Polish border) \\
\hline Kiev - Shytomyr - Rivne - Lviv - Krakovez (Polish border) \\
\hline Kiev - Lviv - Ushhorod (Slovak border) \\
\hline Odessa - Uman - Winnyzja - Chmelnyzky - Ternopil - Luzk - Jahodyn \\
\hline Kiev - Poltava - Charkiv - Luhansk - Iswaryne (Russian border) \\
\hline Kiev - Batschivsk (Russian border) \\
\hline Charkiw - Dnipropetrovsk - Zaporischja - Melitopol - Simferopol \\
\hline Reni - Mykolajiv - Cherson - Melitopol - Berdjansk - Mariupol \\
\hline Kiev - Tscherkassy - Kirovohrad - Mykolajiv \\
\hline Kiev - Poltava - Dnipropetrovsk - Donetsk \\
\hline
\end{tabular}

\section{Inland navigation}

The largest ports in the Odessa region are Odessa, Ilyichevsk and Yuzhny. All three show their greatest importance especially regarding the western economy. The ports are called the ports of 'Greater Odessa' and show close functional cohesion.

The port system of Odessa contributes significantly to the transit potential of Ukraine. Its share of transportation amounts to more than $65 \%$ of the entire sea transit of Ukraine. The high concentration of transportation in the Odessa port system results from a combination of advantageous natural, economic and logistic location factors. In the long run, given these factors, the Odessa harbour complex can be expected to play a leading role inside Ukraine as well as regarding the entire Black Sea region.

Within the urban catchment area of the Odessa port system has developed the largest port agglomeration in the Black Sea region. This consists of the Odessa, the Ilyichevsk and the Yuzhny ports. Each of these ports has specialised in a certain category of goods: the percentage of the sales volume of a commodity group in one of the three ports amounts on average to $80 \%$ and, in the other ports, to $8 \%-12 \%$. The scale effects 
resulting from this specialisation lead to an increase in efficiency for companies using the port system.

River transport in Ukraine is dominated by the state-owned company Ukrretschflot. This association has been transformed into a public limited shipping company. It consists of a main company and 290 structural units. Ukrretschflot is considered to be an important shipping company in Europe. Every year, the shipping company's fleet carries 2.8-3.0m tonnes of cargo.

There are ten important Ukrainian inland ports situated on the rivers Dnepr, Southern Bug and Desna. Cargo is shipped across the Danube, the Black Sea and the Mediterranean, including the use of inland ports in Romania, Germany, Hungary and Austria, as well as the seaports of Turkey, Greece, Israel, France and Italy.

In the Odessa region, the shipping company Black Sea and Inland Passage also exists. This plays an important role in Ukraine's economy, because the firm could attain proceeds of $\$ 1$ bn with its solid heritage from the times of the Soviet Union. Engine facilities and boat systems are currently being repaired because little has been invested in the antiquated ships and facilities, despite their need of repair, since Soviet days. In the 1990s, this most important company in the country was allowed to decay. At that point, the shipping company owned 295 transport and passenger ships and 1100 ships in a supporting fleet, employing more than 28000 employees. Today, the firm is being reorganised and rebuilt, needing many investors in order to compete on the world market. However, its prospects are positive. After the Danube-Black Sea Canal was opened above the Bistroje arm of the Delta on 26 August 2004, reopening the Danube to sea traffic, the first Ukrainian ship through the link was the Roxolana, directed from Ismail via Ilyichevsk to Istanbul. This Ukrainian Danube-sea connection has a total length of $95 \mathrm{~km}$.

The percentage of foreign ships reached more than $35 \%$ in the period from May to December 2007. During these months, the percentage proportion between Ukrainian and foreign fleets was $61.5 \%$ compared to $38.5 \%$. The greatest part of foreign ships originated from Russia. The route was used by a total of 22 countries, including Turkey, Azerbaijan, Georgia, Switzerland and Romania.

Pilots are mandatory on the passage; even so, it is only half as expensive as the Romanian Sulinskij Canal (\$0.14 per sq.m. of ship). A common integration of transport, including the transport connection Danube-Volga-Don, was agreed with Russia on 3 September 2004. This means that the disproportions in the Ukrainian water traffic system can be overcome and new opportunities made to appear for international traffic in the pan-European Danube passage.

\section{Air traffic}

Air traffic in Ukraine is operated by foreign airlines and the so-called State Airlines of Ukraine. Airports numbering 105, as well as companies operating in the area of aeronautics repair, are still state-owned. The largest airports lie in Kiev, Guljani, Luhansk, Donetsk, Odessa, Dnipropetrovsk, Zaporischja and Lviv.

The Ukrainian air shipping market is in the middle of a period of integration into the international transport market and is characterised by the general development 
trends applying in this segment of the world economy. Air cargo shipping shows a positive dynamic: postal and cargo shipping operated by Ukrainian airlines amounted to 67.1 thousand tonnes in 2000 whilst, in 2004, it had increased to 76 thousand tonnes. In 2005 , it further increased by $7.45 \%$ and in 2006 by $8.5 \%$. The entire handling of air cargo by Ukrainian airports increased up to 126 thousand tonnes in 2005, i.e. $26 \%$ up on the preceding year. The great part of this is allotted to charter flights mostly of Ukrainian airlines.

However, talking about a boom in Ukrainian air traffic would be a mistake. The growth of air cargo shipping in Ukraine generally, and that of Ukrainian companies in particular, can be explained as a recovery from its low level in 1999 when political disfavour and economic mistakes caused a crash in air cargo turnover of 11 thousand tonnes.

Furthermore, the market has reflected the political and economic situation of the country during the past years as if a barometer. Market fluctuations are connected to changes in the leadership and structure of the government, as well as to the policies of tariffs and taxes.

Air cargo shipping is going to stay a very sensitive and unstable market, strongly dependent on airline decision-making: the spontaneous actions of airlines can induce owners and cargo agents immediately to shift cargo from air to other types of transportation.

\section{Telecommunications}

The restructuring of the telecommunications sector started in 1993 with the foundation of the state-run company Ukrtelekom. Neither the privatisation of the company nor a deregulation of the sector has yet been conducted. Ukrtelekom holds a leading market position in the area of network services. The company controls the primary network and assures local telephone connections as well as long-distance and international connections. Small local landline providers normally have a tough time because they do not obtain connections into the Ukrtelekom network. The foundation of an independent office of regulation has not yet taken place. In 2001, there were 21.2 telephone users for each 100 inhabitants.

The largest share of sales is held by cellular mobile telephony services, with $62.3 \%$; followed by landline telephony (15.2\% long-distance and international connections as well as $10 \%$ connections in local networks); postal services (4.4\%); computer services, including software and consulting services (4\%); as well as other IT industry services $(4.1 \%)$. In 2007, the growth in sales was especially high in the software industry, which is relatively strong in exports (expanding by $53 \%$ to $\$ 149 \mathrm{~m}$ ). The volume of spend on telecommunications services by private households amounted to $\$ 2.28 \mathrm{bn}$ in the first nine months of the year. Annualised, these numbers are equivalent to a per capita consumption of $\$ 65.50$.

In September 2007, the government rescheduled the privatisation of the state-owned landline network monopoly Ukrtelekom for 2008. Kiev hopes to reach the planned estimate for the entire privatisation revenues in the next year just from the sale of state participation in the company. At the beginning of February 2007, it was told that the government wanted to sell $10 \%$ of its $92.8 \%$ total stake in Ukrtelekom on Ukrainian 
stock exchanges and $32.8 \%$ on foreign stock exchanges; $50 \%$ plus one share would stay in the hands of the state.

\section{Electricity supply}

The spine of the Ukrainian energy industry consists of 44 thermal co-generation plants and eight hydro-electric power plants, as well as four nuclear power plants. The installed electricity generation capacity amounts, all in all, to $54 \mathrm{~m} \mathrm{kw}$; almost one-half of power production originates from nuclear energy since two additional nuclear reactors were commissioned in 2004 (Khmelnytsky and Rivne). The industry has to fight against obsolete production and distribution capacities which cause the loss of a large part of the energy produced. Owing to the high share of energy intensive industries, as well as a relatively low energy efficiency, primary energy needs are extraordinary high. In order to assure electricity supply, Ukraine has to import large volumes of oil and gas, primarily from Russia and Turkmenistan. A total of 27 regional energy distribution companies, the so-called oblenergos, assure the country-wide energy supply; so far, just seven of them have been privatised. The ratification of a law on the disencumberment of the state-run oblenergos is still to be realised. Some of them have accumulated enormous debts because of lengthy delays in payment from their customers and energy prices which have not covered costs.

One critical point consists in the market prices for Ukrainian industrial electricity. Prices in Ukraine are much higher than in Russia and further price increases may be expected. Power charges for Ukrainian households have also been increased. However, electricity tariffs are being held artificially low by government, reflecting the political situation (elections).

\section{Industry structure}

On the territory of the Odessa region, there exist companies from the mechanical engineering and metalworking industry, the chemicals industry and oil, and from food and light industry.

There are also some repair service companies in the mechanical engineering complex in the region: plants for the repair of agricultural machinery and equipment, and for domestic appliances; equipment for light industry and the food industry; workbench repair lines; plants for the production of metals-based armature and equipment for building and metallic packaging; and so forth.

The leading centres of metalworking production in Ukraine are the city of Kiev (2004: $15.1 \%$ of total production) as well as in the areas of Dnipropetrovsk (17.5\%), Donetsk $(10.1 \%)$ and Odessa $(8.25 \%)$. In the Odessa region, the company Stalkanat is in the leading position, with 1900 employees and a turnover of about 200m Ukrainian Hryvnia (UAH). 
Figure 4 - Metalworking industry: production 2004
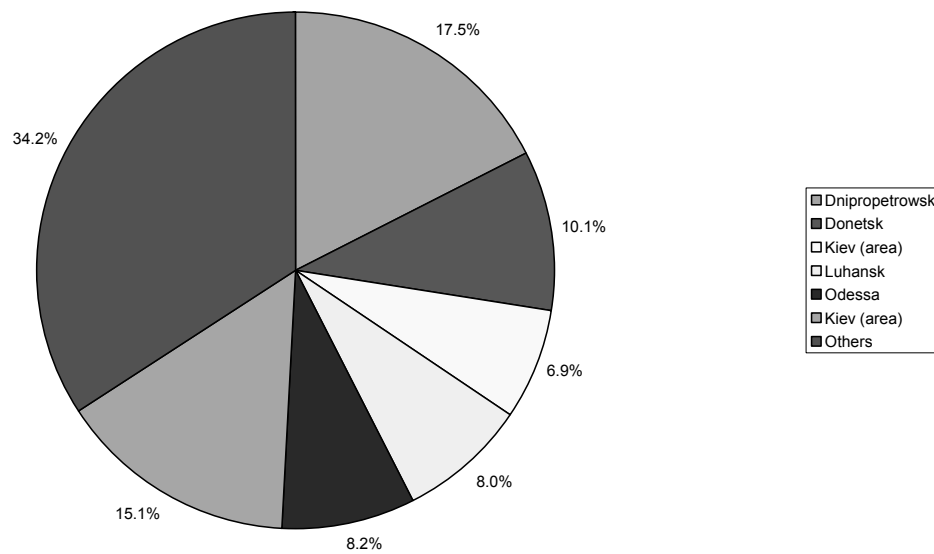

The Odessa region ranks in fifth place in terms of the chemical industry after Donetsk, Luhansk, Dnipropetrovsk and Kiev. The state-owned company Zavod Pryportovyj is in the leading position in the region with about 4000 employees and a turnover of about UAH 1.6bn.

\section{Figure 5 - Chemical industry: production 2004}
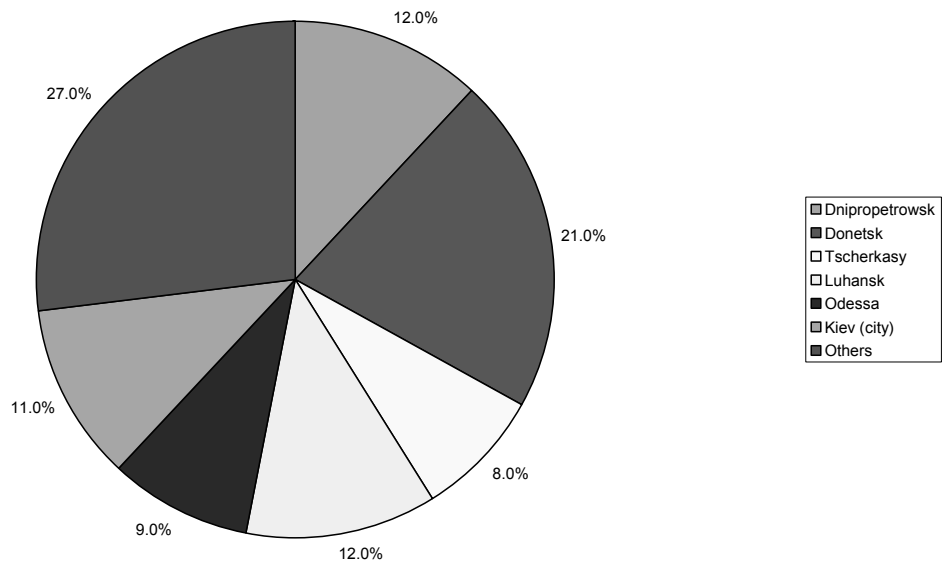

The Odessa region also ranks in fifth place among the leading areas in Ukraine in the ship construction industry. Werf $\mathrm{GmbH}$, with about 2200 employees and turnover in the region of UAH $80 \mathrm{~m}$ turnover, as well as the state-owned company Odesskyj Obavtodor with about 1600 employees and turnover of around UAH 800m, have to be underlined. 
Figure 6 - Shipping construction: production 2004
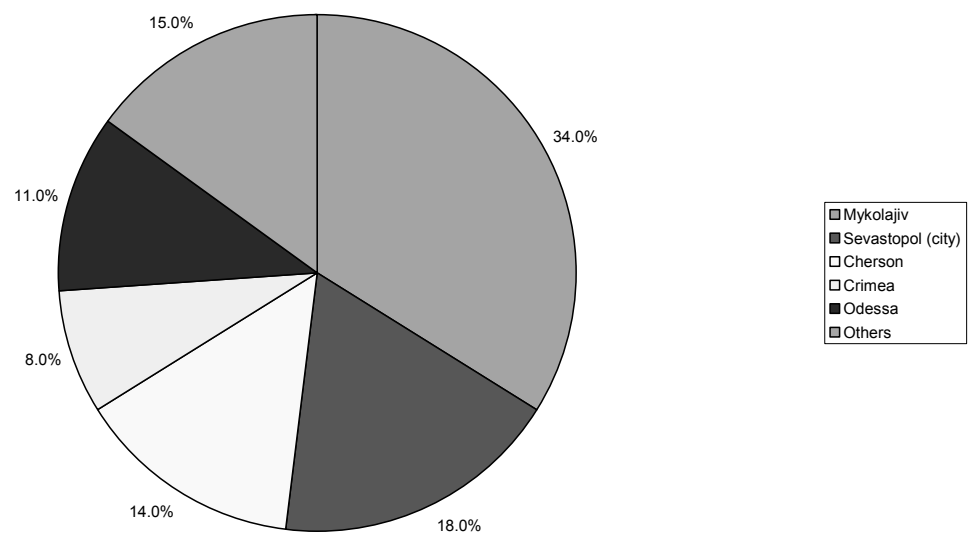

In the transportation system, the Odessa region ranks in second place after the city of Kiev. Here, the state-owned company Odeska Zaliznyzja, with about 60000 employees and a turnover of around UAH 3 bn plays an important role.

\section{Figure 7 - Transportation: turnover 2004}

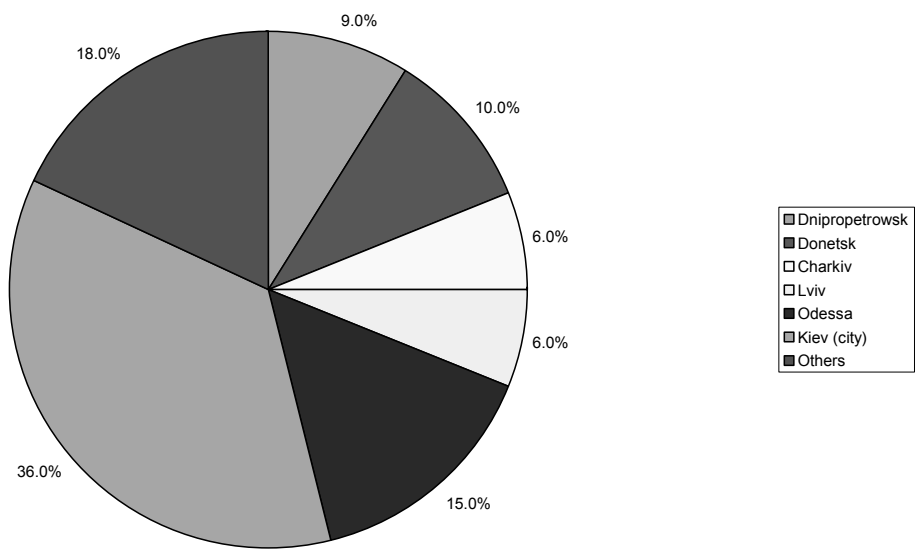

The food industry holds the leading position in the structure of goods production. The production of sugar, butter, fat, tinned vegetables, agricultural commodities, wine, tea and concentrated foods has to be emphasised as major business areas in this sector of the industry within the oblast.

An important role in the inter-regional production complex and in export-import relations is played by meat, tinned milk, alcohol, confectionery, non-alcoholic beer and tobacco. Within the region's structure of industrial production, light industry plays a crucial role. Among the most important branches are the production of drapery and 
sewn products. Aside of this, the cotton, woollens, leather and the fur industry are also widespread. In the shoe and tricot fabric industries, the service sector is well-developed.

Within the region, the following branches of the medical industry are present: the production of pharmaceutical goods and compounds, medical machinery and medical apparatus made of plastic. Companies in the chemical and petrochemical industry produce mineral fertilisers, paint and dye products, chemical products for domestic use and plastic and rubber products. Furthermore, celluloses and cardboard, furniture, wooden and building materials are also produced in the Odessa region.

Other companies which are not directly connected to the local basis of minerals and material resources play an important role at the inter-regional level in the context of Ukraine.

\section{Markets}

In 2006, the industrial companies of the Odessa area sold products totalling more than UAH $12.1 \mathrm{bn}$. Of this, $87.3 \%$ (UAH 10.6bn) is due to manufacturing companies. In the structure of sales volume, mechanical engineering takes the largest part (30\%), followed by the food oils industry $(26.8 \%)$, the chemical and petrochemicals industry $(16.3 \%)$ and the manufacturing and distribution of electric power, gas and water $(12.7 \%)$. An orientation towards the raw materials for industrial production can also be found: the share of raw material products in the total sales volume of the raw materials extraction and manufacturing industry amounts to $38.5 \%$. Investment products take up $30.6 \%$, mass consumer goods $30.1 \%$ and durable consumer goods $0.8 \%$.

The share of the food industry in total industrial production amounts to one-third. In an annual comparison between 2006 and 2005, this industry has grown by $12 \%$. The growing demand of domestic food companies for packing and packaging, and the increase of commercials, have resulted in the increased production of the pulp and paper industry by $18.1 \%$, while special paper and cartons have grown by $7.9 \%$ and corrugated paper and cardboard by $10.9 \%$.

About $8 \%$ of total industry production concerns the metallurgy and metalworking industries. A growth in production of $27.5 \%$ was reached due to energy saving technologies which have decreased the consumption of natural gas. Enterprises in the metal industry generally contribute considerably to the growth of industrial production given their growth in production of $70 \%$.

In 2006, water and pipeline manufacturers (like Reson plc) were able to increase the production of pipes by $25.8 \%$. Machine tool manufacturers, too, can show positive results. Stable conditions for development and new product ranges, and increased demand, were attained due to a continuing increase in quality. Other branches were also very profitable in 2006 (and 2007): metalworking machines (increase of $16.7 \%$ ), press equipment $(55 \%)$, non-metallic mineral products $(16.2 \%)$, electro-technology (24.3\% increase in 2007) and the IT industry (23\% increase in 2007).

The volume of foreign trade in the region of Odessa should, according to the 2007 prognosis of the privy council of the Odessa region, grow to $\$ 3556 \mathrm{bn}$. Compared to 2006 , trade was envisaged as expanding by $4.1 \%$. Within this picture, the export of commodities and services was thought likely to reach $\$ 1789$ bn (a $4.6 \%$ increase on 
2006) and imports $\$ 1767$ (a $3.6 \%$ increase compared to 2006). In this case, a positive balance of $\$ 22 \mathrm{~m}$ would have argued for the further growth of export businesses, especially in the service sector.

Unfortunately, this expert prognosis for 2007 did not prove to be correct: the goal of a positive balance was not reached because exports were lower than estimated. Nevertheless, within exports the proportion taken by services occupies a relatively high level compared to the proportion of this business sector within imports, as Figure 7 demonstrates.

Corn export quotas were abolished by government decree on 8 June 2007. Hence, restrictions on the export of wheat, mixed wheat and mixed corn have been lifted.

Closer co-operation with neighbouring countries and the practical realisation of European and euro-Atlantic integration into the regional market are the most important priorities of the foreign policy of the Odessa region.

Ukraine became a member of the World Trade Organisation in February 2008. The European Union had agreed upon membership in order to negotiate a free trade agreement with the country. Ukraine had until 4 July 2008 to ratify the membership protocol and, thirty days later, it became a full member of the organisation. Experts have commented that Ukraine could pose a number of requests to Russia, especially concerning the energy sector.

\section{Figure 8 - Dynamics of foreign trade of the Odessa region}

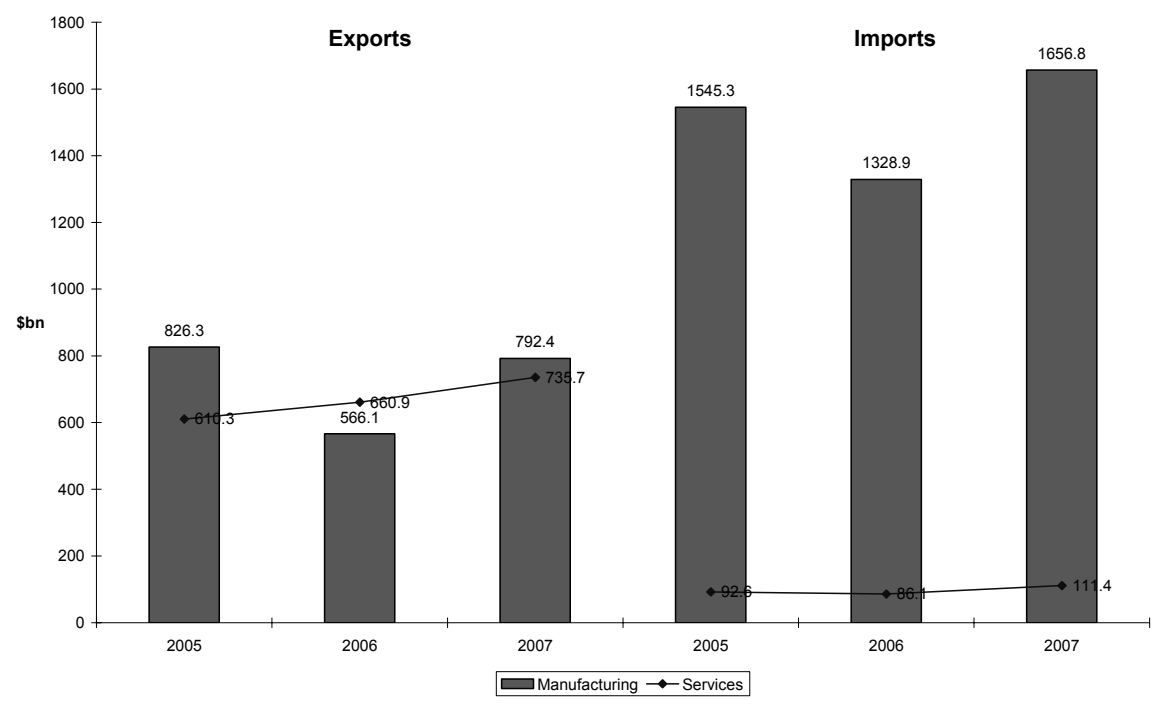

\section{Development potential}

The maritime economy plays a very important role in the strategic development of the Odessa region. This includes sectors like the ship construction and renovation industry, the fishing industry and port management, mechanical engineering regarding the agro- 
industrial complex and the land development of the places of discovery of petroleum and natural gas in the shelf zone of the Black Sea.

Tourism and spas are no less important sectors belonging to the economic potential of the region and to its modern infrastructure.

\section{Table 4 - Development activity required, by industry}

\begin{tabular}{|l|l|}
\hline Industry & \multicolumn{1}{c|}{ Type of activity } \\
\hline Spa system & $\begin{array}{l}\text { Construction and renovation of hotels } \\
\text { development of a modern hotel complex; the maintenance and } \\
\text { Development of a network of spa and rehabilitation (wellness), as well } \\
\text { as other tourist, structures }\end{array}$ \\
\hline $\begin{array}{l}\text { Agro-industrial } \\
\text { complex }\end{array}$ & $\begin{array}{l}\text { Introduction of highly-efficient breeding technologies; renewal and } \\
\text { modernisation on the basis of new technology of processing and food } \\
\text { production companies which provide and preserve agricultural } \\
\text { products }\end{array}$ \\
& $\begin{array}{l}\text { Mechanisation of the existing and the creation of new capacities in the } \\
\text { production of packaging and packaging materials } \\
\text { Development of agricultural mechanical engineering; production of } \\
\text { facilities for the canning industry }\end{array}$ \\
\hline $\begin{array}{l}\text { Light industry } \\
\text { Mechanical }\end{array}$ & $\begin{array}{l}\text { Production of yarns, textiles, clothes, shoes and leatherwear } \\
\text { Production of television and radio installations, electric domestic } \\
\text { for housing and the local economy, ship construction }\end{array}$ \\
\hline $\begin{array}{l}\text { Ponstruction } \\
\text { materials industry }\end{array}$ & $\begin{array}{l}\text { Mining and the extraction of gas and oil } \\
\text { Development of innovative energy producing and saving techniques } \\
\text { Development of the modern production of new construction materials } \\
\text { and products }\end{array}$ \\
\hline $\begin{array}{l}\text { Development of non-traditional modes of energy supply } \\
\text { purposes }\end{array}$ \\
\hline
\end{tabular}




\begin{tabular}{|l|l|}
\hline Industry & \multicolumn{1}{c|}{ Type of activity } \\
\hline Telephony & $\begin{array}{l}\text { Development of modern modes of connection } \\
\text { Development of long-distance telephone communications } \\
\text { Completion and modernisation of postal services }\end{array}$ \\
\hline
\end{tabular}

Rationalising economic-geographic relationships, the following sectors should be preferred: agriculture; transport and telephony; the social sector; and conformity with the industrial orientation of the region. Evidently, the implementation of an active structural policy is necessary in order to balance the spatial relations of the economy in the Odessa region. The goals of such a structural policy should include:

- developing specific products for this region

- developing favourable conditions for the encouragement of industrial sectors based on services, assuring the social needs of the population

- promoting the existing industry sectors

- maintaining agricultural industrial production and its intensification through farming companies and other agricultural enterprises.

The structural transformation of the macroeconomic framework should be borne in mind as a necessary precondition in order to ameliorate the socio-economic situation of the region. In order to achieve this, a rational co-ordination of regional and national interests should be focused on, as well as the promotion of those industry sectors which have good competitive prospects on the world market.

\section{Opportunities and risks}

Thus far, Germany, with a share of $30 \%$, or $\$ 7 \mathrm{bn}$, is absolutely the largest foreign investor in Ukraine. At the moment, there exist in Ukraine around 1200 companies with German participation, 330 of which are subsidiaries, 250 are representative offices and 620 are joint ventures. Germany is not only the largest investor, but the second most important trading partner of Ukraine after Russia.

Table 5 - Important milestones of German foreign direct investment (BfAI)

\begin{tabular}{|l|c|c|c|}
\hline German direct investment & $\mathbf{2 0 0 4}$ & $\mathbf{2 0 0 5}$ & $\mathbf{2 0 0 6}$ \\
\hline Cumulative stock $(\$ \mathrm{~m}$, beginning of each year) & 449.9 & 652.0 & 5503.8 \\
\hline Net accrual $(\$ \mathrm{~m})$ & 202.1 & 4851.8 & 116.9 \\
\hline
\end{tabular}

On the country's development scale, Odessa ranks in second position after Kiev. This includes far-reaching goals such as the foundation of a business park (with planned investments of $€ 2 \mathrm{bn}$ ), Ukraine's largest Black Sea port and the enlargement of the spa and tourism sector. In the course of the next few years, the priorities will lie in the construction plans for the development of small- to medium-sized businesses in the area of transportation and the traffic system, road construction, food manufacturing and light industry, the energy sector and the reconstruction of existing traffic networks, as 
well as the new building of sanatorium and clinic complexes and hotels - especially taking into consideration the visitors which are to be expected during the 2012 European Football Championship.

Ukraine attracts investors primarily through its strongly increasing market potential in the construction sector in which local products also have the chance of a high market share.

Today, some observers already view Ukraine as the future outsourcing location following the Chinese example but on the borders of Europe. With labour costs ranging at less than $5 \%$ of the EU average, Ukraine could become an attractive production location for European industry if it succeeds in aligning its framework to market economic standards and in stabilising the trust of investors.

Table 6 - Important milestones of foreign direct investment (BfAI; \$m, as at 1 January 2007)

\begin{tabular}{|l|c|}
\hline Region & Cumulative foreign direct investment \\
\hline Kiev (city) & 5338 \\
\hline Dnipropetrovsk & 2332 \\
\hline Charkiv & 1015 \\
\hline Kiev (region) & 879 \\
\hline Donetsk & 837 \\
\hline Odessa & 704 \\
\hline Zaporischja & 610 \\
\hline Autonomic Republic of Krim (Simferopol) & 577 \\
\hline Lviv & 509 \\
\hline Poltava & 310 \\
\hline Transkarpaten (Ushhorod) & 298 \\
\hline Luhansk & 284 \\
\hline Wolhynien (Luzk) & 275 \\
\hline Other regions & 1441 \\
\hline Residual foreign investment (cumulative) & 21.186 \\
\hline
\end{tabular}

The district of Odessa takes fifth place among the regions of Ukraine regarding the volume of foreign investment. In the first quarter of 2006, the total amount of separate foreign investment in the economy of the area of Odessa reached $\$ 635.8 \mathrm{~m}$, of which $\$ 104.9 \mathrm{~m}$ represented direct investment. The 715 enterprises in the area have a total share of $\$ 594.9 \mathrm{~m}$ in their business property. In the course of $2005, \$ 98.8 \mathrm{~m}$ was invested in regional enterprises - $\$ 36.7 \mathrm{~m}$ lower than in the previous year. Surprisingly, only $\$ 1.1 \mathrm{~m}$ originated from CIS countries, even though co-operation is emphasised repea- 
tedly. In the area of portfolio investment, foreign investors show greater cautiousness: in the first quarter of 2006, 49 enterprises in the Odessa area received in total just $\$ 6.3 \mathrm{~m}$.

Recently, major foreign corporations have invested in the economy without starting up new enterprises. Certain projects, such as the ports system, are of specific interest to investors (especially the centres for cargo handling in the ports, parts of the petroleum industry and some enterprises belonging to the metal engineering sector and the food manufacturing industry).

Foreign investors are interested in those economic areas of the region showing the highest capital turnover and in those cities showing a developed infrastructure. This is connected to the high rates of turnover of invested capital and smaller risks. Such industries include domestic trade, which has a share of $17.6 \%$ of overall foreign investment, transportation $(15.8 \%)$, food industry $(13.3 \%)$, construction $(10.1 \%)$, mechanical engineering and metalworking $(9.3 \%)$, and the crude oil processing industry $(7.9 \%)$.

Aside of the money and credit economy, the sectors thought likely to be targeted by foreign direct investment in the next few years would include, probably above all, the real estate sector, the construction and construction materials industry, wholesale and retail, healthcare and the pharmaceuticals industry and the insurance business, as well as some sectors in mining and manufacturing industry.

Among the latter, the iron and steel industry is more than ever dependent on external capital and know-how: it was mentioned above that this sector struggles with very high average energy consumption coefficients compared to the international picture.

The spirits and the fishing industries, the construction and real estate industries and the insurance business count as 'sensitive' industries taking a high share of the informal economy and featuring business crime particularly strongly. Cases of international money laundering, as well as attacks from so-called corporate raiders on property and shareholder rights, accumulate in these sectors. Investors need to proceed very carefully when choosing Ukrainian partners.

Ukraine ranks in $128^{\text {th }}$ position out of 175 countries, according to the World Bank report Doing Business in 2007. A comparison can quickly be made: Russia performed better, in $96^{\text {th }}$ position, while Belarus was a little inferior, in 129th place. Ukraine appeared particularly backward on the Index of Investment Protection, occupying 142nd position. On a rating scale from 0 (no investment protection at all) to 10 , it scored a value of 2.7 (Russia 5.0). The Ukraine tax system ranked in 174th position in the appropriate index, just above Belarus (175). Ukraine achieved a very weak rating regarding the protection of property rights, taking $133^{\text {rd }}$ position. 
Table 7 shows that Ukraine is the most challenged in this area out of the 175 countries in the ratings:

Table 7 - Doing business rating of selected countries, 2007 (BfAI)

\begin{tabular}{|l|c|c|c|c|}
\hline Criteria & Ukraine & Russia & Belarus & $\begin{array}{c}\text { Republic } \\
\text { of Moldova }\end{array}$ \\
\hline Establishment of an enterprise & $101(110)$ & $33(31)$ & $148(136)$ & $84(69)$ \\
\hline Assignment of licences & $107(98)$ & $163(143)$ & $84(73)$ & $119(63)$ \\
\hline Attitude and regard of workers & $107(119)$ & $87(57)$ & $31(55)$ & $128(135)$ \\
\hline Protection from vested titles & $133(127)$ & $44(35)$ & $96(82)$ & $47(40)$ \\
\hline Access to credit & $65(75)$ & $159(148)$ & $117(61)$ & $101(97)$ \\
\hline Investor protection & $142(141)$ & $60(73)$ & $142(110)$ & $99(89)$ \\
\hline $\begin{array}{l}\text { System of controls (bureaucratic } \\
\text { expenditure, delivery load) }\end{array}$ & $174(151)$ & $98(52)$ & $175(154)$ & $119(89)$ \\
\hline $\begin{array}{l}\text { Imports and exports procedure } \\
\text { (bureaucratic expenditure and costs) }\end{array}$ & $106(78)$ & $143(67)$ & $113(65)$ & $105(80)$ \\
\hline $\begin{array}{l}\text { Conclusion of contract; Asserting } \\
\text { contractual and other rights; } \\
\text { Administrative expenses and costs }\end{array}$ & $26(39)$ & $25(62)$ & $36(52)$ & $55(66)$ \\
\hline $\begin{array}{l}\text { Establishment of enterprise } \\
\text { (duration and cost to completion) }\end{array}$ & $139(123)$ & $81(71)$ & $91(85)$ & $78(72)$ \\
\hline
\end{tabular}

Furthermore, the legal security of investors suffers from uncertainties and contradictions regarding the effective legal rules, as well as frequent changes in the legislation. 'Informal' business takes a share of $50 \%$ to $60 \%$ of 'official' GDP, according to Ukrainian economists. In planning major projects in the Odessa region, or in Ukraine generally, one has to face the need to influence politicians. Furthermore, bad payment behaviour does, unfortunately, have to be faced in Ukraine. Therefore, advance payments tend to be preferred.

The Odessa region contributes significantly to the development of foreign trade relations and by attracting foreign investors to the regional economy. The region realises many joint international projects and programmes, three of the most important of which in 2007 were:

- International Forum of Investment and Innovation

- International Assembly for Tourism Business

- Celebrate Europe Day in Odessa Region

The Odessa region promotes economic relations with countries such as Germany, Italy (in particular Tuscany), Greece, China, Bulgaria, Poland, Romania, Russia and Belarus. Co-operation prioritises the international infrastructure of the transportation system as a whole, the ocean-going vessel industry, ship equipment and repair, the wine industry, 
tourism, agriculture, chemical industry and information and communications technology, as well as the food industry.

Figure 9 - Structure of foreign direct investment for 2006 in the Odessa region (total: $\$ 681.3 \mathrm{~m})^{5}$
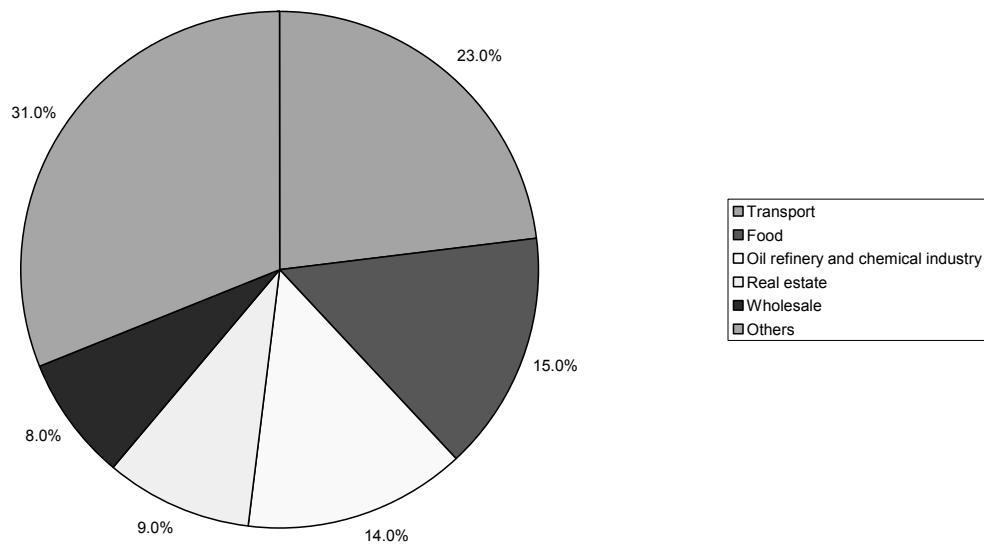

Figure 10 - Sources of foreign investment in the Odessa region in $2005^{6}$

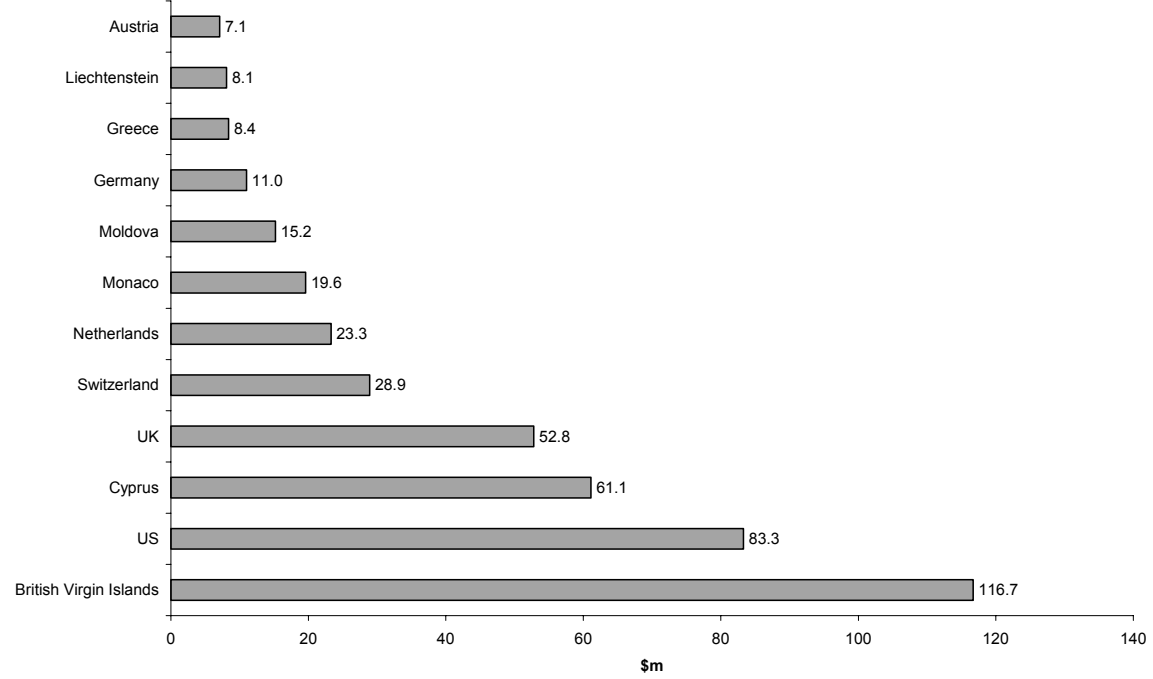

Supported by foreign diplomatic and business circles, enterprises in the Odessa region need to learn perspectives and foreign trade business.

5 Cf. Programme for the development of Odessa region Council of the Odessa Oblast.

6 Ibid. 
The use of economic panels and seminars are planned to serve as support mechanisms on the way to European standards. The 'Bavarian House' in Odessa, with its headquarters in Munich, may be mentioned as an example here. The Bavarian House serves as a teaching centre for languages and offers the Ukrainian-Bavarian Management Training Centre (UBMT).

The UBMT's programme provides Ukrainian citizens with knowledge and support in starting up a business and gives foreign investors the possibility of getting to know the Ukrainian economy. The basic features of the programme are business administration, such as financing, investments, marketing and logistics, as well as production management, human resource management and many other areas of a company. Aside of language training, inter-cultural knowledge and the development of business relations are also imparted.

The Odessa region participates in the economic and cultural life of Europe, being a member of six international organisations:

- Assembly of European Regions (AER)

- Association of European Border Regions (AEBR)

- Danube Region Working Community (ARGE Donauländer)

- Assembly of European Wine-Producing Regions (AREV)

- Conference of Peripheral Maritime Regions (CPMR)

- Organisation of the Black Sea Economic Co-operation (BSEC).

The most important project of cross border co-operation which is being worked on at the moment is the European region 'The Lower Danube', which unites three Romanian regions (Galați, Braila and Tulcea), three districts of the Republic of Moldavia (Vulcanest, Kagul and Kantemir) and the Odessa region.

Investments, too, play an important role in the economic growth of a country and of a region such as Odessa. The investments of companies and organisations in 2006 amounted to UAH $3965.4 \mathrm{~m}$. More than four-fifths of this was invested in initial capital, e.g. in the construction and purchase of facilities and equipment: all in all, an increase of investment of $24.1 \%$ compared to the previous year.

The structural analysis of investment in initial capital reflects an increase in the value of enterprises and organisations in the Odessa region. 
Figure 11 - Volume and indices of investment in initial capital for 1990-2007 in the Odessa region ${ }^{7}$

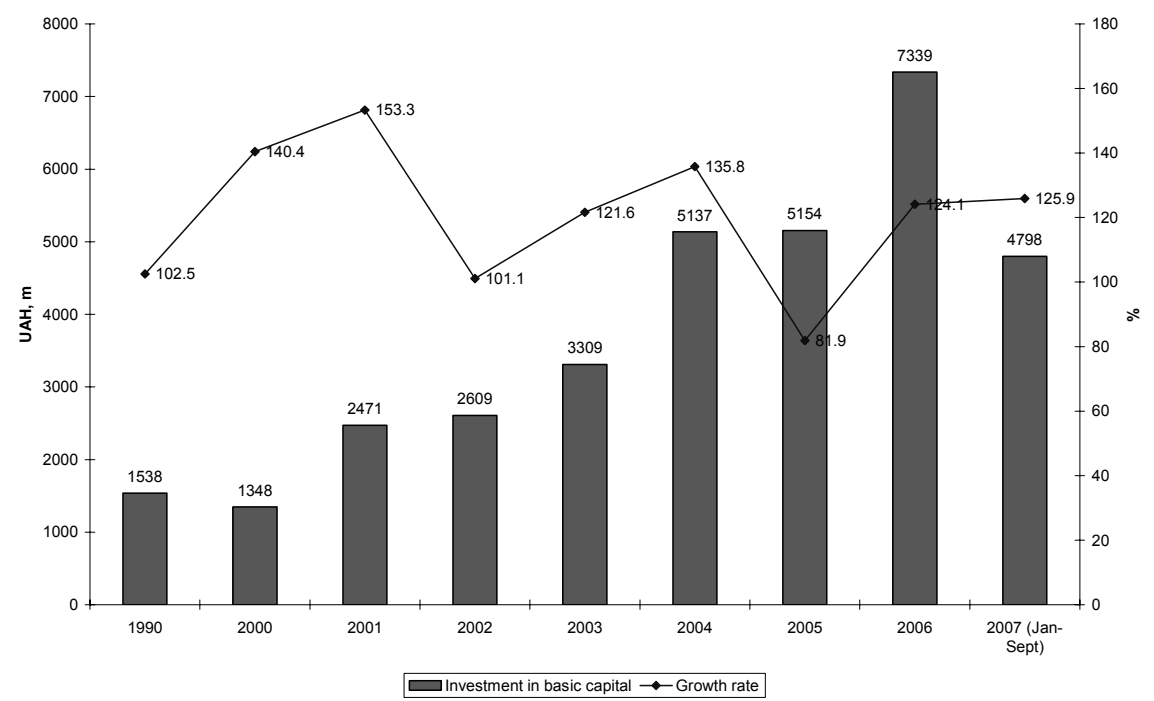

\section{Risks and measures to reduce them}

General risks as regards the investment climate result from the macroeconomic framework of Ukraine.

Instability of legislation

The weak majority constellations of the parties who form the government lead to an instability in legislation. This causes legal insecurity and a lacking authority in implementing laws.

\section{Energy supply}

The energy sector is threatened by unpredictable volatility because of the dependence on foreign energy suppliers. Russia, for example, argues that price increases for deliveries into the Ukraine have been necessary in order to adapt price levels to world market prices. Some important energy companies are already showing high levels of debt, but they have also had problems in enforcing their own legitimate outstanding debts.

All in all, there are difficulties which investors will face in the area of basic supplies and infrastructure. 


\section{Banks}

Most of the banks are badly capitalised. Hence, they might not be able to handle major financial pressure and, in the worst case scenario, they run the risk of not being able to cover the claims of their creditors.

\section{Danger of inflation}

Recently, inflation has again increased threateningly and the danger of a slowdown in economic growth requires rapid economic and fiscal political action. Without the foundation of economic growth, far-reaching reforms can barely be imagined. Inflation will stay at high levels in Ukraine because of the price increases for oil and gas: this can cause negative effects in the national budget as well as in foreign trade.

\section{Emigration of intellectual elites and skilled workers}

Separate regions of Ukraine show tendencies of a 'brain drain'. Problems with filling jobs at management level have to be confronted, because the intellectual elite and skilled workers - important pillars of economic construction - could soon be in shortage.

Fitch and Standard \& Poor's, the credit ratings agencies, rated Ukraine a 'BB outlook stable' in October 2006. Foreign investors orient themselves around these ratings. 'BB - outlook stable' means that country risks exist, government bonds are of medium quality and protection against changing economic development is lacking. Moody's assigns a similar rating and talks about the low long-term security of debt payments. Legal insecurity and insufficient compliance with contracts, as well as an under-developed banking sector, are crucial risk factors for investors.

Insider dealings in Ukrainian politics and the economy might represent a certain kind of stability but, if one does not swim with their current, i.e. chooses not to cooperate or contribute, one would probably face resistance if not even insuperable barriers. Often, talk can be heard of a certain percentage of corruption payment which additionally had to be dealt with. Smaller 'presents' for civil servants suffice, but these additional costs are not really calculable.

Foreign firms have particular difficulties in gaining ground in Ukraine. Bureaucracy plays a large role hereby because it leads to very long waiting times. The degree of bureaucracy in Ukraine is very high and, for some foreign companies, the procedures become an ordeal. In this area, comprehension should not go missing. The authorities are very concerned about new enterprises, but they give only little support. Bargaining with the government is difficult, too, because it does not necessarily stand by an agreement.

The search for the right co-operation partner can be made difficult by several factors: the non-transparent organisational structures of Ukrainian firms, in which a request might not find a responsible person and end up in the wastebasket; the complex and, from a Ukrainian perspective, non-comprehensive requests of foreign companies the translation of which would be too time-consuming, to say nothing of the subsequent adjustment to technical norms; and the unrealistic expectations about price on both sides. 
In Ukraine, it is difficult to view balance sheets which are in accordance with international standards of accounting. However, the German Investment and Development Association and Pricewaterhousecooper have recently emphasised the necessity of having such balance sheets at one's disposal which are in accordance with international standards. This would be in the interests of financial investing companies which are thereby given an important tool for their financial decision-making aside of the provision of a business plan.

Even so, problems with the infrastructure ought to be underlined: telecommunications are not developed sufficiently in the country; while the transport infrastructure is also unsatisfactory. These risk factors can affect the business capacity of an enterprise.

The risks are, in summary:

- unstable legislation

- difficulties with implementing the law

- little protection of investment and economic interests

- risks of infrastructure deficiency

- unreliable transportation network, especially for transit freight

- insecurity with debt payments

- delay in bank transfers

- unstable tariff regulation and resultant difficulties with border and tariff services

- incalculable corruption payments

- difficulties in finding qualified on-site managerial staff

- contempt of licensing laws (illegal copying, infringement of copyright).

Indeed, the Ukrainian government has declared its intentions to reduce investment risks and improve the framework for foreign business partners. However, one needs to face up to the difficulty that intention and realty often diverge in Ukraine. Hence, it is important to bear in mind the interaction of the numerous economic, fiscal and legal factors and the need to integrate country-specific peculiarities into planning right from the beginning. The taking on of a qualified western-shaped consultant, and the early assignment of skilled personnel with long-standing Ukraine experience, are recommended. At least, analysis and assessment by experts confident in their on-site knowledge, including a careful consideration of opportunities and risks, is suggested.

Everywhere in Ukraine, the search for a supplier being both interesting and willing to co-operate requires much time and patience. After all, the potential supplier must not only lower costs to gain the account but also comply with quality standards, guarantee a certain degree of flexibility and minimise the emergence of risks. The search for a suitable partner in the Ukrainian market can be arranged in two ways: intra-corporate; or with the help of external experts.

With intra-corporate searching, the international branches of the chamber of commerce, numerous databases, catalogues and b2b fairs are useful. When it comes to a search by external consultants, market research may be conducted based on practical experiences and personal relations.

When an interesting potential supplier is found, it is always recommended to send a representative to Ukraine who can carefully examine the partner company. In this way, important insights can be gained into whether the company might enter conside- 
ration for co-operation; if its machinery is up to state-of-the-art; and if product quality is in accordance with the requirements of foreign purchasers. When choosing a cooperation partner, one must look for how reliable, motivated and ready for action they are in order to avoid any attempt which might occur simply to copy western products.

Information on product capacity, i.e. adaptability to increasing customer demands, is important in terms of strategic decision-making. A large part of the difficulties and risks in the process of establishing co-operation can be avoided, or delegated, by leaving the selection of suppliers to a professional partner. Such a partner should possess profound knowledge about the habits and market situation in Ukraine and should visit foreign companies who are searching appropriate suppliers in their own countries as well as on-site.

Joint ventures should only be developed when the local partner can contribute substantially to the success of an investment project ('added value'), for example by providing important market knowledge or building up important contacts with the local administration. The choice of a business partner should be assured by provided information and carefully-chosen modes of payment and insurance. Choosing either the irrevocable confirmed letter of credit or prepayment is advisable as a mode of payment for transactions with Ukraine; both these means of payment seem to be functioning reliably in Ukraine. However, in using prepayments, a term of ninety days has to be considered within which the payment might occur (control of exchanges).

By all means, a lawyer with in-country experience should be consulted in order to safeguard contracts. A foreign trade office can intervene on request in terms of collecting debts. In entering the Ukrainian market, a national trade office can play an important role in opening up a variety of opportunities in initiating businesses and providing service features.

The most important principles of minimising risks are, in brief:

- have clearly-defined goals for external advisors (high motivation is necessary)

- do not trust first impressions

- pay attention to mentalities (have knowledge of mentality and business habits)

- compile a catalogue of measures before final decision-making (assessment of risks and opportunities)

- do not bargain with the bureaucracy on one's own account (establish contacts with contact people who know the official offices)

- observe the internal and external development stages of the market economy

- have one's own translators

- institute training programmes

- seek business entry with western managerial staff (sales skills)

- assign as a project manager someone of trust who has experience in the Odessa region (insider knowledge is a crucial precondition), as well as market knowledge and access (many emigrants have excellent contacts)

- assign an experienced controller from the head office (as the bearer of know-how)

- safeguard contracts through a lawyer familiar with the country

- avoid payment gaps by establishing rules on prepayments. 


\section{Medium-term economic perspectives}

The Odessa region, like the other regions of Ukraine, attracts foreign investors for the following main reasons:

- low-cost production for export into the EU

- establishing a sales presence on the domestic market

- creating a head office for trade in eastern Europe.

Furthermore, the Odessa region possesses particular geographic and infrastructural strengths which could form the basis for a more far-reaching, even more commerciallyshaped, development.

According to a SWOT analysis, ${ }^{8}$ the international image of the oblast and the city of Odessa is positively above-average and strong foreign trade relations already exist. It also underlines the activity of the local authorities in important areas:

- developing the service sector

- improving the innovation and investment climate

- building the Kiev-Odessa motorway

- modernising and developing the port industry.

Institutions like the World Bank or the European Bank for Reconstruction and Development, which are financing large projects in the energy sector or in infrastructure, might also assist.

The regional strategy programme for the development of the Odessa region over the next few years promotes several projects aimed at stabilisation, competitiveness, modernisation and the development of the region in the areas of transportation, agriculture, tourism, industry, the development of entrepreneurship, energy, education and foreign trade. Furthermore, large-scale investment projects by foreign investors from Germany, China, Scandinavia and central and eastern European countries will contribute to the region's development in the next years.

In 2008, the oil pipeline Odessa-Brody, extending to Poland, is planned to be further developed into a connection between Asia and Europe. This project, however, still needs reliable investors.

Odessa is already an established region for spas, but it wants to be regarded as a multi-faceted centre. Hence, a railway line needs to be built between the ports at Suchoj and Odessa in order to ease the transportation of cargo between the two landing places. An aspect regarding sea and road transportation is, furthermore, the active market demand for Ukrainian capacities by container loading sites. Much will be invested in this industry. For instance, a container terminal with capacities of $2-2.5 \mathrm{~m}$ TEU is going to be built by the Privat group.

Additionally, co-operation with a Polish company led to a joint venture intending to build a ship construction plant in 2008. A joint venture named Huba Ukraine emerged from the Ukrainian Transsibgas and the Chinese Huba Construction Machinery; it plans the construction of a plant specialising in tower cranes.

8 See Annex. 
Work on the reconstruction and repair of Odessa International Airport is planned as a part of the preparations for the 2012 European Football Championship. The Ukrainian Treasury has bankrolled UAH $1117 \mathrm{bn}$ for the reconstruction, as well as a subsidy of UAH 36m. The European Football Championship is an investment factor which could be a springboard because many hotels, restaurants, roads and railway lines are going to be built in the Odessa region. According to the German Office for Foreign Trade, an increase of investment of at least $15 \%$ may be expected. Accession to the WTO in February 2008 should also lead to an advance of investments.

Good growth opportunities arise from the geographic position, especially in the transportation system (improved transit facilities). According to the SWOT analysis, the last few years indicate a constant increase in transportation and transit capacities.

Today, active economic co-operation with other countries on the Black Sea (Turkey, Bulgaria, Georgia, and also Greece) already exists, for example in the form of the BSEC. Additionally, there are memberships of European international associations, such as the VRE, AGEG and the ARGE Donauländer. The government of Ukraine even aspires to access the EU as a full member. However, this rather seems to be a long-term objective.

\section{Conclusion}

The geographic position of the Odessa region favours two industries which are important, even seminal, for the domestic as well as the export market. On the one hand, the tourism industry has to be mentioned: the region is attractive to foreign tourists and patients of health spas because of its wide coasts and the Mediterranean climate. On the other hand, there is the transportation industry, especially the port industry with the largest Ukrainian port on the internationally-navigated Black Sea. Furthermore, the entire Ukraine profits from its function as an important transit country from the EU to the Commonwealth of Independent States and to Asia.

Politically, the country's population is (still) heavily divided between EU supporters and Russia sympathisers. For instance, about $90 \%$ of the western part of the population of Ukraine recently voted in favour of the EU while about $90 \%$ of the eastern part of the population voted in favour of Russia. Even at almost seventeen years of distance from the commencement of independence from Russia, both democracy and the market economy are still young and immature. According to polls of the Ukrainian population, trust in politicians is clearly lacking. Politicians are predominantly estimated as lacking in decision-making competences and being corrupt. Thus, it is hard to assess how well the country will be able in the future to free itself from this 'schizophrenic' and corrupt image and, hence, to communicate an improved level of political stability. An external way out of being torn between east and west could be neutrality: Ukraine could declare itself neutral regarding foreign affairs in order to avoid alienating one of the two sides - following the example of Switzerland.

Unfortunately, the country's instability affects the legal situation and also the banking sector. Here, a weak spot obviously exists and reforms are needed.

Thus, investing in this country at the moment requires a certain deal of courage and an awareness of the hazards thereby taken. 
In the view of western mentalities, a re-thinking might be required when one talks, for example, of budgets for corruption payments. However, measures such as credit assessment and the hedging of outstanding money have been common for a long period in Ukraine. Those who want to play it totally safe should insist right from the start, and with all types of businesses, on prepayments.

The violation of licensing laws is, of course, rather difficult to guard against although it should be estimated positively that deceptions in the legal and banking system are made transparent and are even discussed and actively confronted in politics.

The economic backwardness of the country itself offers particular development and growth opportunities for the economy and the wealth of the region. In my opinion, Odessa still thinks more positively and open-mindedly about the future than other regions of Ukraine, especially the eastern ones. Low production costs help the country to attract investment and deliver economic growth, hence promoting an adjustment of the large prosperity gap.

Counting about $48 \mathrm{~m}$ inhabitants, there exists in Ukraine a huge and exciting emerging market for, for example, German industry. There is still a great need for modernisation - a situation which needs to be actively confronted and which will instigate a huge demand for products which are technologically state-of-the-art. Indeed, the industrial plants of Odessa are obsolete and huge wasters of energy. However, the port facilities are today already showing a ray of hope: the port industry in the Odessa region can count on a modern infrastructure, especially regarding container traffic.

An analysis of the single industries of the country has shown that some sectors are already exhibiting enormous growth, for example the construction and telecommunications industries. In some building material sectors, the market is booming, with increases in sales of $20 \%$ per year.

Furthermore, the region is already a large recipient of foreign direct investment, including from Germany. The construction industry, the food industry, the transportation sector and the oil and chemical industries are profiting from this. German companies are internationally very strong in energy-saving and non-polluting industrial techniques and, hence, particular sales opportunities exist here. Additionally, the outsourcing strategies of foreign enterprises offer a wide range of potential for co-operation. In European comparison, Odessa has exceedingly low wage levels, but it does score with a workforce which is well-skilled and above-average on the basis of regional comparison. One has only to think about the software industry.

In the long run, one might well speculate about the EU accession of Ukraine. Even in the population of the EU, there is support for this. According to a poll conducted in France, the EU population is able to conceive of Ukraine as a further member state aside of Russia, while countries like Turkey or Morocco are placed much further behind (according to a programme aired by the TV channel Arte in August 2007). This might be due to the EU only being able to grow towards the east and, hence, Ukraine would logically be the next step.

At the very least, I could observe in the Odessa region a remarkable energy, with parts of the population which are no longer backward and which demonstrate a strong will to develop the country economically. The country is becoming aware that no grea- 
ter development opportunities would exist in the country without a balanced co-operation with foreign investors.

The Odessa region is already a member of a large number of trade associations and marketing boards, especially in the network of states bordering the Black Sea, but with other countries as well. Odessa is often seen as a motor of growth for the entire Ukraine other than Kiev. Additionally, the 2012 European Football Championship being parthosted in Ukraine (and therefore in Odessa, too) could - aside of a gain in image for the country - be a positive impulse for investment and, hence, promote growth and wealth for the hosts. 


\section{ANNEX}

\section{SWOT analysis}

The SWOT analysis is an easy and flexible method with which internal regional strengths and weaknesses and opportunities and threats can be identified. Such an analysis is very useful as a tool for strategic management in order to make location analyses for a company planning to enter the market in the Odessa region. The chart shows the above-mentioned aspects, illustrating once more why the Odessa region is very attractive for economic activity on the one hand while, on the other, it demonstrates what kind of threats are associated with this. The weaknesses mainly lay in an antiquated infrastructure.

\section{Table 8 - SWOT analysis of Odessa region ${ }^{9}$}

\section{Opportunities and threats profile:}

\begin{tabular}{|l|l|l|}
\hline Area & \multicolumn{1}{|c|}{ Opportunities } & \multicolumn{1}{|c|}{ Threats } \\
\hline $\begin{array}{l}\text { Geographical and } \\
\text { geopolitical } \\
\text { situation/ } \\
\begin{array}{l}\text { Potential of natural } \\
\text { resources }\end{array}\end{array}$ & $\begin{array}{l}\text { Active co-operation with the } \\
\text { countries of the Black Sea } \\
\text { Membership of European } \\
\text { international associations } \\
\text { Transit options across the territory }\end{array}$ & $\begin{array}{l}\text { Peripheral position of the oblast } \\
\text { territory compared to the capital of } \\
\text { Ukraine }\end{array}$ \\
$\begin{array}{l}\text { Open border to Moldova and } \\
\text { Pridnestrovia } \\
\text { and the city of Odessa }\end{array}$ \\
\hline $\begin{array}{l}\text { Population/ } \\
\text { demography of the river route offered } \\
\text { by the Danube }\end{array}$
\end{tabular}

9 Zaslawskij G (2004) Problemi mishrajonnoj subregionalizazii Odessa, p. 44-47. 


\begin{tabular}{|l|l|l|}
\hline Area & \multicolumn{1}{|c|}{ Opportunities } & \multicolumn{1}{c|}{ Threats } \\
\hline $\begin{array}{l}\text { Employment/ } \\
\text { employment } \\
\text { possibilities }\end{array}$ & $\begin{array}{l}\text { Employees of international } \\
\text { consultants in the education sector } \\
\text { of regional business representatives }\end{array}$ & 'Brain drain' \\
\hline Infrastructure & $\begin{array}{l}\text { Transition of the } \text { oblast territory } \\
\text { through the route of some } \\
\text { international transport corridors } \\
\text { Construction of the ship passage of } \\
\text { the Ukrainian part of the Danube } \\
\text { delta } \\
\text { Building the Kiev-Odessa } \\
\text { motorway }\end{array}$ & $\begin{array}{l}\text { Unsatisfactory level of } \\
\text { development of the transportation } \\
\text { network for transit journeys }\end{array}$ \\
$\begin{array}{l}\text { Active modernisaltios with border and tariff } \\
\text { development of the port industry }\end{array}$ & \multicolumn{2}{|l}{} \\
\hline
\end{tabular}

Strengths and weaknesses profile:

\begin{tabular}{|c|c|c|}
\hline Area & Strengths & Weaknesses \\
\hline $\begin{array}{l}\text { Geographical and } \\
\text { geopolitical } \\
\text { situation/ } \\
\text { Potential of natural } \\
\text { resources }\end{array}$ & $\begin{array}{l}\text { Proximity of sea and border } \\
\text { Connection with the shipping } \\
\text { rivers Danube and Dnestr } \\
\text { Important agricultural and climatic } \\
\text { resources } \\
\text { Long coastline }\end{array}$ & $\begin{array}{l}\text { Non-compact territory } \\
\text { Great distance of rural districts } \\
\text { from the administrative centre of } \\
\text { the oblast } \\
\text { Weak mineral and raw material } \\
\text { basis } \\
\text { Few water resources, especially } \\
\text { potable water }\end{array}$ \\
\hline $\begin{array}{l}\text { Population/ } \\
\text { demography }\end{array}$ & $\begin{array}{l}\text { High entrepreneurial activity of the } \\
\text { citizens } \\
\text { High share of a well-skilled } \\
\text { workforce } \\
\text { High share of graduates }\end{array}$ & $\begin{array}{l}\text { High share of elder citizens } \\
\text { Increasing share of immigrants in } \\
\text { the domestic population } \\
\text { Relatively low life expectancy of } \\
\text { citizens } \\
\text { High mortality rate of children } \\
\text { Decrease in the population } \\
\text { Labour migration of residents }\end{array}$ \\
\hline
\end{tabular}




\begin{tabular}{|c|c|c|}
\hline Area & Strengths & Weaknesses \\
\hline Economy & $\begin{array}{l}\text { Developed sea complex } \\
\text { Industry } \\
\text { Agriculture } \\
\text { Existence of particular business } \\
\text { zones } \\
\text { Existence of territories with } \\
\text { industrial perspectives } \\
\text { Many sight-seeing opportunities } \\
\text { Active development of the } \\
\text { financial and credit system }\end{array}$ & $\begin{array}{l}\text { Excessive regulation of business } \\
\text { activities } \\
\text { A large number of industrial } \\
\text { companies have ceased production } \\
\text { Long-lasting process of economic } \\
\text { reforms } \\
\text { Large intra-regional differences in } \\
\text { socio-economic development } \\
\text { Crucial concentration of the } \\
\text { economic potential in few cities in } \\
\text { the oblast } \\
\text { Considerable share of the } \\
\text { population with very low income } \\
\text { levels } \\
\text { Low internal energy security } \\
\text { High interest rates }\end{array}$ \\
\hline $\begin{array}{l}\text { Employment/ } \\
\text { employment } \\
\text { opportunities }\end{array}$ & $\begin{array}{l}\text { Low official level of } \\
\text { unemployment } \\
\text { High proportion of employees in } \\
\text { the service sector }\end{array}$ & $\begin{array}{l}\text { Large intra-regional differences in } \\
\text { the workforce } \\
\text { Unsatisfactory youth employment } \\
\text { Limited employment opportunities } \\
\text { in the periphery }\end{array}$ \\
\hline Infrastructure & $\begin{array}{l}\text { Existence of all kinds of traffic } \\
\text { Active process of telephonisation }\end{array}$ & $\begin{array}{l}\text { Insufficient development of the } \\
\text { motorway network in the periphery } \\
\text { Weak transport connections with } \\
\text { that part of the oblast behind the } \\
\text { Dnestr } \\
\text { Unsatisfactory water supply and } \\
\text { disposal } \\
\text { Low level of development of the } \\
\text { social infrastructure }\end{array}$ \\
\hline
\end{tabular}

Even though the government paramountly prioritises economic development, implementation is very difficult due to the unstable political situation of the country and the bureaucracy, as well as the uncertain situation concerning legal security, which is not always given. Hence, the involvement of foreign investors is still rather small. However, the region is very interesting to foreign investors and its development indeed does have high potential. 